\title{
Red Blood Cell Sensitization Due to Unexpected Rh Antibodies in Immune Serum Globulin
}

\author{
H. A. Oberman, and M. L. Beck \\ From the Blood Bank Section, Department of Pathology, The University of Michigan, \\ Ann Arbor, Michigan
}

\begin{abstract}
A newborn infant developed red blood cell sensitization due to anti-D following administration of immune serum globulin (human). The lot of administered immune serum globulin contained an unexpectedly high titer of anti-D. This should stimulate passage of federal regulations requiring absence of significant levels of blood group antibodies in such products.
\end{abstract}

The unanticipated presence in biologic products prepared from human plasma of antibodies directed against red blood cell antigens may cause harmful side effects in the recipients. We previously reported accelerated red blood cell removal in hemophiliacs given Factor VIII preparations containing high levels of $\mathrm{ABO}$ antibodies. 3 , 5

In the course of performing direct antiglobulin tests on all patient blood specimens sent to our laboratory, the following example of red blood cell sensitization due to anti-D was noted. The case is of more than passing interest, for previously administered immune serum globulin proved to be the source of the antibody.

Received for publication June 3, 1971; accepted July $23,1971$.

\section{Case Report}

This 25-day-old male infant was admitted to the University of Michigan Medical Center because of persistent weight loss and anemia. He was born with a large omphalocele, which was repaired four hours after his birth. Twelve days postoperatively persistent vomiting and constipation led to a diagnosis of intestinal obstruction, and necessitated reexploration. Adhesions were lysed but no cause for the obstruction was found.

Upon admission to this hospital the baby weighed $4 \mathrm{lb} 13 \mathrm{oz}$, representing a loss of almost two pounds since birth. Laboratory studies included, Hemoglobin, $9.8 \mathrm{~g} / 100 \mathrm{ml}$; hematocrit, 28 per cent; total serum protein, $4.2 \mathrm{~g} / 100 \mathrm{ml}$; and serum albumin, $2.5 \mathrm{~g} / 100 \mathrm{ml}$. X-rays of the small intestines revealed markedly delayed transit of barium; 24 hours were required for it to reach the colon. Following transfusion of $20 \mathrm{ml}$ of red blood cells, a plastic catheter was inserted in the superior vena cava and a hyperalimentation regimen was instituted on the fifth hospital day.

The hyperalimentation resulted in weight gain and moderate elevation of serum proteins. However, persistent fever began two weeks later and Candida parapsilosis was cultured from the infant's blood, urine and from the catheter. The infant continued to manifest hypogammaglobulinemia; immunodiffusion revealed the following values: IgA, $23 \mathrm{mg}$ per $100 \mathrm{ml}$; IgM, $105 \mathrm{mg}$ per $100 \mathrm{ml}$; and IgG, $150 \mathrm{mg}$ per $100 \mathrm{ml}$.

Because of the mycotic infection and the persistent hypogammaglobulinemia, $2.5 \mathrm{ml}$ of 16.5 per cent immune serum globulin were administered intramuscularly, and an intravenous regimen of amphotericin B was instituted. When blood was 
requested for transfusion eight days later, a positive direct antiglobulin test was detected.

\section{Serologic Findings}

The patient received four transfusions of red blood cells, ranging from 20 to $40 \mathrm{ml}$, prior to the detection of the positive direct antiglobulin test. On each occasion his red blood cells typed as A, Rh-positive, the direct antiglobulin test was negative, and no unexpected antibodies were present in his serum. Similar serologic findings were present at birth, prior to the omphalocele repair. The baby's mother's red blood cells typed as $\mathrm{O}, \mathrm{Rh}$-positive, and no unexpected antibodies were present in her serum.

The positive direct antiglobulin reaction could be inhibited by prior addition of $\gamma$ globulin to the antiglobulin serum, indicating red blood cell sensitization with an IgG antibody. Eluates from the baby's red blood cells manifested unequivocal anti-D and anti-C specificity. No antibody was detectable in the infant's serum.

The four units of blood from which the baby received transfusions were confirmed as being $A, R h$-positive. The recent advent of red blood cell sensitization suggested that the antibody had been passively administered, most likely in the immune serum globulin.

The titer of anti-D in the lot of immune serum globulin administered to the baby was $1: 256$ and the anti-C titer was $1: 4$, as determined by the antiglobulin technic. Three other sources of immune serum globulin either lacked anti-D activity or had titers of 1:2. Another lot of immune serum globulin from the same commercial source as that given the baby had an anti$D$ titer of $1: 16$. No anti-C activity was present in any lot except that given to the patient.

\section{Discussion}

The red blood cell sensitization manifested by this infant almost certainly was due to the immune serum globulin admin- istered eight days earlier. Previous direct antiglobulin tests on the patient's red blood cells had been negative consistently and an unusually high titer of anti-D was present in the lot of $\gamma$ globulin.

Each lot of commercially prepared immune serum globulin represents a pooling of approximately equal amounts of plasma from at least 1,000 donors. ${ }^{1}$ Because of this dilutional effect it is highly unlikely that the level of anti-D in this plasma could have resulted on a random donor selection basis. Another possibility is the inclusion in the pool of plasma from large numbers of Rh-negative donors with anti-D, whose titer proved inadequate to permit their use in $\mathrm{Rh}$ immune globulin production.

We were unable to document accelerated removal of the sensitized red blood cells from this baby's circulation. Nevertheless, the positive direct antiglobulin test had a deleterious effect by delaying transfusion while the cause of the reaction was elucidated. Such levels of hemagglutinin in immune serum globulin may assume more than theoretical importance. Small amounts of anti-D can enhance immunization of $\mathrm{Rh}$-negative persons who receive Rh-positive red blood cells, 4,6 as in small feto-maternal hemorrhages during pregnancy, or in administration of Rh-positive platelet preparations. Two documented failures of $\mathrm{Rh}$ immune globulin to prevent immunization of Rh-negative mothers have been attributed to administration of rubella immune globulin early in pregnancy. 2,4

We previously have documented the untoward effects of administration of $\mathrm{ABO}$ antibodies in Factor VIII preparations and noted occurrence of unwanted high levels of such antibodies in these pooled plasma derivatives. ${ }^{3,5}$ Similarly, Pollack determined that most lots of commercial $\gamma$ globulins contained low concentrations of anti$\mathrm{Rh}$ and other red blood cell antibodies. ${ }^{4}$ The level of anti-D in the lot of immune 
serum globulin given to our patient cannot be considered a "low concentration."

At present no requirement exists in the Public Health Service Regulations for Biologic Products for ascertaining the presence and titer of red blood cell antibodies in immune globulin preparations. ${ }^{1}$ It seems both appropriate and necessary that there be a federal requirement that antibody levels be determined for each lot, and that those pools of plasma with significant levels be diverted to other uses.

\section{References}

1. Biological Products-Public Health Service Regulations-title 42, part 73. Department of Health, Education and Welfare, Division of Biologics Standards, National Institutes of Health, Bethesda, Md., 1969, pp. 82, 84.

2. Finn, R.: Liverpool experience with $R \mathrm{~h}$ immunoglobulin. Transfusion 8: 143, 1968.
3. Oberman, H. A., B. Barnes, and P. L. Ginther: Erythrocyte sensitization and anemia due to isoantibodies in lyophilized pooled plasma. JAMA 198: 323, 1966.

4. Pollack, W., J. G. Gorman, and V. J. Freda: Prevention of $\mathrm{Rh}$ hemolytic disease. In Progress in Hematology, vol. 6, E. B. Brown and C. V. Moore, Eds. New York, Grune and Stratton, 1968.

5. Rosati, L. A., B. Barnes, H. A. Oberman, and J. A. Penner: Hemolytic anemia due to anti-A in concentrated antihemophilic factor preparations. Transfusion 10: 139, 1970.

6. Siskind, G. W.: The role of circulating antibody in the control of antibody synthesis: mechanism for the suppressive effect of passive antibody on active antibody synthesis. lbid. 8: 127, 1968.

Harold A. Oberman, M.D., Professor of Pathology and Medical Director of Blood Bank, University of Michigan Medical Center, Ann Arbor, Michigan 48104. (Correspondence)

Malcolm L. Beck. F.I.M.L.T., Research Technologist, Blood Bank Section, Department of Pathology, University of Michigan Medical Center.

\section{STATEMENT OF OWNERSHIP, MANAGEMENT AND CIRCULATION}

(Act of August 12, 1970: Section 3685. Title 39. United States Code)

Date of Filing-September 24, 1971.

Title of Publication-Trassfusios.

Frequency of Issue - Bi-monthly.

Location of Known Office of Publication--East Washington Square, Philadelphia, $\mathrm{Pa} .19105$.

Location of the Headquarters or General Business Offices of the Publishers-East Washington Square, Philadelphia, Pa. 19105.

Publisher-y. B. Lippincott Company, East Washington Square, Philadelphia, Pa. 19105.

Editor-Richard E. Rosenfield, M.D., Mount Sinai Hospital, 100th Street \& Fifth Avenue, New York, N. Y. 10029.

Managing Editor-George F. Stickley, East Washington Square, Philadel phia, Pa. 19105.

Owner-J. B. Lippincott Co., East Washington Square, Philadelphia, $\mathbf{P a}$.

Known Bondholders, Mortgagees, and other security holders owning or holding 1 per cent or more of total amount of bonds, mortgages or other securities: Anderson \& Co. Philadelphia, Pa.; Steere \& Co., Philadelphia, Pa.; Joseph Wharton Lippincott Bethayres, Pa.; Girard Trust Corn Wharton Lippincott, Bethayres, Pa.; Girard Trust Corm Trustees u/w/o, Marianna L. O'N eill, Dec'd., PhiladelTrustees u/w/o Marianna L. O'Neill, Dec'd., Philadel
phia, Pa.; Fidelity-Philadelphia Trust Co., Trustee, Est. phia, Pa.; Fidelity-Philadelphia Trust Co., Trustee, Est. Bauernfeind, Bryn Mawr, Pa.; George Stevers, Kingston, N. J.; Joseph W. Lippincott, Jr., Haverford Pa.; Cross \& Co. Philadelphia, Pa.; Bertram Lippincott, Penllyn, Pa.; Elsie L. Chadwick, Duxbury Mass.; Barton H. Li.; King of Prussia. Pa.; Sarah Louise Lamb, Devon, $\mathbf{P a}_{\text {a.; }}$ Robert B. \& Elizabeth $H$. Powell as joint tenants with right of survivorship, Balboa, Calif.; Wilhelmina K. Ball,
Philadelphia, Pa.; Trustees under J. B. Lippincott Co.'s Employees' Profit Sharing Trust dated 12/27/44, Philadelphia, $\mathbf{P a}$.

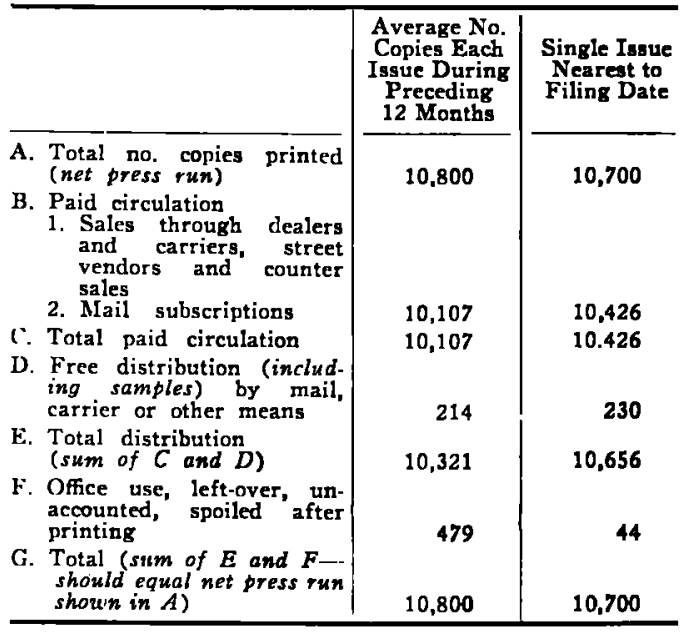

I certify that the statements made by me above are crrect and complete.

JOHN M. WeHner, JR., Business Manager 